\title{
DESAIN BALANCED SCORECARD TERINTEGRASI DENGAN PENDEKATAN SIX SIGMA
}

\author{
Iman Supriadi \\ Sekolah Tinggi Ilmu Ekonomi Mahardhika Surabaya \\ iman@stiemahardhika.ac.id
}

\begin{abstract}
The motivation behind this paper is to give new bits of knowledge into understanding the estimation of incorporating the Balanced Scorecard with Six Sigma. This paper depends on an exhaustive writing audit from BSC and Six Sigma. The writing survey gives the premise to another joining system dependent on the PDCA cycle. The discoveries of this paper show how coordinated frameworks can add further esteem contrasted with the autonomous execution of either BSC or Six Sigma. This investigation gives a structure that can fill in as a reason for the reconciliation of Six Sigma with BSC. This paper adopts another strategy to joining structures by recognizing purposes of incorporation influence through the qualities and shortcomings of BSC and Six Sigma. The fundamental commitment of this paper is that it gives new experiences into seeing how BSC can be coordinated with Six Sigma. In addition, this paper gives guidance for future research that will defeat shortcomings in the manner associations are coordinating BSC with Six Sigma today.
\end{abstract}

Keywords: Balanced scorecard; Integration; PDCA; Six Sigma; Total quality management.

\section{PENDAHULUAN}

Kualitas kemampuan sebuah organisasi atau individu bisa diketahui dengan pengukuran kapasitas atas pencapaian serta mutu yang berhasil diperolehan organisasi tersebut. Saat ini, organisasi bekerja di lingkungan global yang penuh dengan kompetisi. Lingkungan usaha yang kian lebih fluktuatif dengan organisasi di penjuru dunia dimana dalam menghadapi rintangan yang semakin besar seperti bertambahnya kompetisi, tuntutan konsumen serta resiko sebagai dampak dari krisis global. Tingkat kapasitas organisasi lebih penting saat ini dibanding organisasi terdahulu. Six Sigma adalah salah satu dari pendekatan organisasi untuk proses peningkatan dan keunggulan operasional yang telah ada sejak 1980-an. Demikian pula, Balanced Scorecard (BSC) yang telah memberikan kerangka kerja organisasi untuk mengubah strategi organisasi menjadi matriks kinerja "berwawasan ke depan" yang akan membantu organisasi dalam mencapai kesempurnaan. Meskipun banyak penelitian tentang Six Sigma dan Balanced Scorecard, integrasi tersebut adalah topik yang menarik untuk diteliti. Berdasarkan kajian literatur yang diperoleh dari penelitian terdahulu ditemukan bahwa masih jarang penelitian saat ini yang mengkaji tentang integrasi Six Sigma dengan Balanced Scorecard. 
Kurangnya penelitian yang mengkaji tentang integrasi kedua metode ini, bukan berarti hal tersebut tidak mampu diimplementasikan dalam sistem organisasi yang ada saat ini. Sebagai contoh, Digital Six Sigma dari Motorola yang diperkenalkan pada tahun 2003 ke Motorola, ditambatkan dengan kartu skor dan dipercepat atau dieksekusi melalui pelatihan, pekerjaan proyek, dan tinjauan proyek (Huesing, 2008). Sehubungan dengan tantangan kompleks yang dihadapi organisasi, dikatakan bahwa "cara terbaik untuk mencapai dan mempertahankan tingkat baru keunggulan organisasi" dapat "mengintegrasikan Six Sigma dengan Balanced Scorecard" (Schultz, 2010). Schultz (2010) lebih lanjut menambahkan bahwa "alat manajemen yang kuat dapat dibuat melalui penyatuan dua strategi yang terbukti ini". Digital Six Sigma Motorola (Huesing, 2008) memberikan kepercayaan kepada sejumlah pandangan penulis tentang integrasi Six Sigma dengan strategi organisasi. Para penulis ini (Antony et al., 2005, 2006; Coronado dan Antony, 2002; McAdam dan Lafferty, 2004; Snee, 2010) telah menyoroti pentingnya menghubungkan Six Sigma dengan strategi organisasi secara keseluruhan. Juga, Neely et al. (2004) membuat referensi ke integrasi Balanced Scorecard: Apakah organisasi tidak menambah Balanced Scorecard dengan metodologi dan / atau program peningkatan yang sesuai? (Neely et al., 2004, p. 768). Oleh karena itu, tujuan keseluruhan dari makalah ini adalah untuk memperdalam pemahaman tentang nilai integrasi Balanced Scorecard dengan Six Sigma untuk peningkatan kinerja organisasi.

Dari pemahaman secara garis besar tentang pengetahuan Six Sigma dan Balanced Scorecard, penelitian ini menjawab beberapa pertanyaan yaitu; apa kekuatan dan kelemahan Balanced Scorecard serta Six Sigma, Bagaimana kekuatan dan kelemahan tersebut dapat dimanfaatkan untuk pengembangan kerangka kerja yang menyatukan kedua metode tersebut dn terakhir bagaimana Kerangka kerja untuk Balanced Scorecard Integrasi Six sigma. Makalah ini disusun dalam tiga bagian; bagian pertama memberikan gambaran singkat tentang Six Sigma dan Balanced Scorecard dari sudut pandang asal mula, manfaat dan tingkat adopsi. Bagian kedua menjelaskan dan mengevaluasi kekuatan dan kelemahan BSC dan Six Sigma dalam konteks integrasi gabungan. Bagian ketiga memberikan kerangka kerja baru yang didasarkan pada evaluasi di bagian dua dan membahas implikasinya.

\section{KAJIAN PUSTAKA}

\section{Pendekatan Six Sigma}

Six Sigma ialah satu metodologi peningkatan terus terusan yang fokus pada konsumen dimana bisa meminimalisir cacat serta variasi sampai 3,4 defects per million opportunities dalam design produk, produksi, serta proses administrasi (Valles, Sanchez, Noriega, \& Nunez, 2009). Six sigma tidak sama dengan cara pengendalian kualitas yang lain sebab cara ini tidak sekedar hanya tingkatkan performansi, tetapi langkah untuk mengubah budaya korporasi dari atas sampai ke bawah (Thomsett, 2005). Disamping itu, six sigma menyertakan pemanfaatan alat 
statistik dengan metodologi terancang untuk mendapatkan proses yang lebih baik, cepat, serta efektif. Pendekatan Six Sigma yang terancang serta terus-terusan dapat memberi keringanan dalam mengukur pencapaian perbaikan kualitas hingga dikehendaki bisa mengenali pemicu ketidakberhasilan yang mungkin sekaligus juga mengurangi defect. Penelitian-penelitian sebelumnya yang berkaitan dengan six sigma banyak dikerjakan oleh peneliti trdahulu.

Deamonita (2018) mengimplementasikan metode Six Sigma sebagai pengendalian kualitas untuk meminimalisir produk cacat tas tali batik di PT XYZ dimana terjadi penambahan nilai sigma dari 3,61 jadi 4,18. Ahmed dkk. (2018) mengaplikasikan six sigma pada perusahaan industri home appliance serta dapat turunkan jumlahnya defect sebesar 4,39\%. Riset itu mempunyai metodologi yang sama yakni DMAIC dengan studi masalah yang berlainan. Disamping itu, Phengky Pangestu (2019) menerapkan Six Sigma dalam Penambahan Kualitas Proses Produks LED TV di PT Sharp Electronics Indonesia dimana nilai Cpk di hasil simulasi alami penambahan semasing jadi sebesar 1,$1 ; 1,11$; serta 1,12 . Para peneliti berpendapat bahwa tolls yang disediakan Six Sigma mampu meningkatkan performance perusahaan.

\section{Pendekatan Balanced Scorecard}

Balanced Scorecard merupakan sebuah skema instrumentasi bagi aktor usaha untuk mengatur organisasi perusahaan buat mentranslasikan misi serta visi perusahaan ke dalam kerangka pengukuran strategis pada beberapa kumpulan standar di dalam masing-masing perspektif yang mendalam, hingga bisa tingkatkan potensi kerja perusahaan untuk membuat daya saing yang berkepanjangan. Ke empat perspektif dalam balanced scorecard adalah satu kesatuan yang tidak bisa dipisah, sama-sama lengkapi jadi sinyal pengukuran kapasitas serta mempunyai interaksi sebab akibat. Perspektif keuangan adalah muara atau hasil akhir dari tiga perspektif yang lain. Untuk mengukur kapasitas finansial perusahaan dikerjakan dengan memandang indikator keuangan mencakup tingkat keuntungan, tingkat penjualan, serta efisiensi biaya. Perspektif konsumen ditingkatkan berdasar hasil riset awalnya meliputi : potensi untuk memperoleh keyakinan konsumen, jalinan yang baik dengan konsumen baik internal atau external, potensi menjaga konsumen lama serta service pada konsumen. Perspektif pelanggan ini tentukan bagaimana perspektif proses bisnis internal bisa terwujud yang di dalamnya ada indikator-indikator layanan yang sudah mempunyai standard, produk yang memberi kepuasan customer serta service retur pembelian. Sedang perspektif pertumbuhan serta pembelajaran menitik beratkan pada infrastruktur perusahaan dimana karyawan jadi asset perusahaan yang bertindak jadi ujung tombak perusahaan dalam memberi produk perusahaaan yang bisa berbentuk barang atau layanan. Jadi cara ini sama-sama berkaitan di antara yang satu yang yang lain hingga membuat satu keadaan yang balanced di antara finansial dengan banyak faktor yang memberi dukungan tercapainya financial perusahaan yang diinginkan (Narayanamma, 2017). 
Dari perspektif manfaat Balanced scorecard, banyak penulis berpendapat bahwa terdapat kekurangan dari bukti empiris (Bourne et al., 2002; Neely et al., 2004; Nørreklit, 2000). Namun, terdapat data statistik yang perlu diperhatikan yaitu dari Lewy (McCunn, 1998, hlm. 34) yang mengklaim bahwa 70 persen implementasi BSC telah gagal. Dalam upaya mengungkap alasan kegagalan tersebut, Lewy (McCunn, 1998) bersama dengan Lex Du Mee dari konsultasi manajemen KPMG, menemukan melalui studi kasus pada tujuh perusahaan Eropa, bahwa hanya perusahaanperusahaan yang telah mengikuti sebagian besar "sepuluh instruksi penerapan Balanced scorecard" yang dapat mengklaim telah berhasil melakukan root scorecard. "Dalam pelaporan mereka serta mengendalikan proses "(McCunn, 1998, hlm. 34). McCunn (1998, hlm. 34) menambah karya Lewy dengan mengedepankan perintah ke-11 untuk dipertimbangkan dengan statement bahwa "Jangan mulai mengimplementasikan kartu skor sampai organisasi tahu apa yang ingin di capai. Serupa dengan Ten Commandments Olve et al. (1999), yang memperkenalkan langkah-langkah yang akan "mendorong dukungan untuk peningkatan BSC" (Amaratunga et al., 2001, hal. 186). Pedoman implementasi ini juga berfungsi untuk menyoroti pentingnya memiliki proses manajemen perubahan yang kuat di dalam organisasi sebelum memulai inisiatif apa pun seperti implementasi BSC, Rekayasa Ulang Proses Bisnis, Lean atau Agile. Jika itu adalah kasus dimana organisasi terusmenerus ditantang oleh manajemen perubahan, maka organisasi mungkin perlu menilai terlebih dahulu di mana ia diposisikan pada tangga pertumbuhan organisasi, misalnya menggunakan Greiner's Model (Rowe and White, 2009). Sebagai kesimpulan, adopsi Balanced Scorecard sebagai tools perubahan proses manajemen yang kuat, mengkomunikasikan fokus strategis di seluruh organisasi, mendorong pandangan perilaku ke depan dan pada gilirannya mengkomunikasikan tingkat komitmen dan kinerja yang lebih tinggi.

\section{METODE PENELITIAN}

Dalam prosedur proses penelitian, satu set metode ilmiah umum dan khusus yang bersifat kognitif digunakan. Jenis penelitian ini adalah kualitatif dimana dalam mempelajari posisi teoritis dan Kekuatan serta Kelemahan BSC dan Six Sigma. Sejumlah penulis memberikan wawasan tentang kelemahan dari kerangka BSC (misalnya De Waal, 2003; Epstein dan Manzoni, 1998; Neely et al., 2004, 2005; Nørreklit, 2000; Othman, 2008; Schneiderman, 1999) dan metodologi Six Sigma (mis. Coronado dan Antony, 2002; Antony, 2004; Douglas et al., 2009, Goh et al., 2006; Hendricks dan Kelbaugh, 1998; Pepper and Spedding, 2010). Menurut Othman (2008), misalnya, BSC adalah rabun dan "Mengabaikan kegiatan dan inisiatif yang melampaui target asli" (p.261). Demikian pula, Self (2004) berpendapat bahwa BSC dapat menyoroti masalah, tetapi tidak mampu memberikan solusinya. Juga, dalam sebuah wawancara dengan De Waal (2003), David Norton menyinggung keterbatasan ini, dimana dikatakan bahwa BSC adalah ahli dalam apa yang harus diukur, bukan dalam cara dalam mengukur (De Waal, 2003, hal. 33). 
Adapun kekutan Balanced Scorecard menurut para pakar dan peneliti terdahulu yaitu diantaranya istilah "balanced scorecard" mencerminkan keseimbangan antara tujuan jangka pendek dan jangka panjang, langkah-langkah keuangan dan non- keuangan, indikator tertinggal dan terkemuka dan perspektif kinerja eksternal dan internal (Hepworth, 1998, p. 560). Nilai tambah dari balanced scorecard (BSC) adalah dalam menyatukan semua area bisnis utama dan mengidentifikasi dan mengeksploitasi hubungan yang memberikan kesuksesan (Hepworth, 1998, p. 560). Balanced scorecard membantu organisasi "mempertahankan perspektif holistik dengan memberikan tampilan ringkas matriks kinerja" (Pyzdek, 2004, hlm. 22). Ini memungkinkan perusahaan untuk melacak hasil keuangan sekaligus memantau kemajuan dalam membangun kemampuan dan memperoleh aset tidak berwujud yang mereka butuhkan untuk pertumbuhan di masa depan (Kaplan dan Norton, 2007, hal. 150). Scorecard menempatkan strategi dan visi, bukan kontrol, di pusat (Kaplan dan Norton, 1992, hal. 79). BSC menerjemahkan misi dan strategi organisasi ke dalam serangkaian ukuran kinerja yang menyediakan kerangka kerja untuk pengukuran dan manajemen strategis (Kaplan dan Norton, 1996b, hal. 2). BSC menyediakan model yang menerjemahkan visi dan strategi organisasi menjadi tujuan strategis spesifik, dipantau melalui serangkaian indikator kinerja yang koheren (Solano et al., 2003, hal. 68). BSC berbeda dari sistem pengukuran strategis lainnya karena mengandung ukuran hasil dan pendorong kinerja hasil, dihubungkan bersama dalam hubungan sebab-akibat" (Nørreklit, 2000, hal. 67).

Masalah pertama yang dihadapi banyak perusahaan adalah kesadaran bahwa tim manajemen puncak tidak dapat mengartikulasikan pandangan yang jelas dan berbagi tentang strategi perusahaan; dalam beberapa kasus, strateginya tidak jelas, dalam kasus lain anggota tim manajemen puncak memiliki pandangan yang berbeda tentang apa strategi perusahaan seharusnya atau seharusnya (Epstein dan Manzoni, 1998, hal. 198). Itu tidak termasuk perspektif pesaing (Neely et al., 2005, p. 1244). BSC tidak memberikan solusi untuk "Bagaimana mengukur?" David Norton mengatakan, "Kami adalah ahli dalam apa yang diukur, bukan dalam cara mengukur" (De Waal, 2003, hal. 33). "Itu dapat menunjukkan masalah, tetapi tidak menikmatinya" (Self, 2004, hal. 104). BSC "dipandang sebagai rabun dan mengabaikan kegiatan dan inisiatif yang melampaui target asli" (Othman, 2008, p. 261). Nørreklit (2000) menyimpulkan dari analisis bahwa "kausalitas yang diklaim dimiliki antara perspektif adalah masalah" (p. 76). Untuk menjadi sukses, BSC harus dipandang sebagai ujung gunung es perbaikan (Schneiderman, 1999, hal. 6). Tidak ada sistem penyebaran yang memecah tujuan tingkat tinggi ke tingkat sub- proses, di mana kegiatan peningkatan aktual berada (Schneiderman, 1999, hal. 7). BSC dapat dikritik karena tidak "mengambil pandangan yang cukup luas dari para pemangku kepentingan yang berinteraksi dengan organisasi" (Neely et al., 2001, hal. 12).

Kekuatan sebenarnya dari Six Sigma terletak pada metodologi penyelesaian masalah loop tertutup yang dibawanya ke bisnis yang akan membantu menjaga 
organisasi pada "jalur yang sering diputar untuk kinerja dan kesuksesan" (Pande et al., 2000, hal. 200 ). Secara spesifik, Six Sigma menyediakan bisnis dengan alat terstruktur untuk mendefinisikan masalah bisnis melalui suara pelanggan, mengukur baseline kinerja, dan memprioritaskan akar penyebab untuk implementasi dan kontrol solusi. Semua pemecahan masalah terstruktur ini berfungsi untuk meningkatkan matriks Six Sigma atau matriks Critical to Quality. Jadi, peningkatan dalam matriks Six Sigma ini secara kolektif dapat memengaruhi matriks kinerja tingkat tinggi dari BSC. Misalnya, jika pelanggan tertentu memerlukan pengurangan waktu tunggu selama dua hari untuk Kepuasan pelanggan 100 persen, maka organisasi dapat memperkenalkan program Six Sigma yang secara langsung akan mempengaruhi perspektif kepuasan pelanggan dari BSC. Jadi, menggabungkan Six Sigma dengan BSC akan mengatasi "ketidakmampuan untuk memberikan solusi jalan "kelemahan BSC dan memberikan kemampuan pemecahan masalah untuk matriks kinerja tingkat tinggi di BSC. Hal ini juga dapat menangkal kelemahan Six Sigma yang yang dijelaskan oleh Antony et al. (2006) dimana manajemen senior di banyak organisasi melihat Six Sigma sebagai inisiatif peningkatan kualitas menurut pandangan mereka. Hal ini dapat mengakibatkan Six Sigma dioperasikan sebagai inisiatif peningkatan mandiri tanpa kaitan dengan strategi organisasi. Putuskan ini dapat membantu menjelaskan David Fitzgerald melaporkan "bahwa kurang dari 10\% dari perusahaan yang melakukannya ke titik di mana ia akan secara signifikan mempengaruhi neraca dan harga saham dalam periode waktu yang berarti" (Coronado dan Antony, 2002, hlm. 92).

Pada tema yang sama, Coronado dan Antony (2002, p. 95) lebih lanjut menambahkan bahwa Six Sigma tidak dapat diperlakukan sebagai strategi mandiri dan bahwa menghubungkan Six Sigma dengan strategi bisnis adalah salah satu faktor penentu keberhasilan untuk keberhasilan penyebaran Six Sigma. Pandangan Coronado dan Antony (2002) tentang pemutusan antara strategi dan Six Sigma juga konsisten dengan pandangan Asif et al. (2009) tentang mengapa program TQM gagal. Asif et al. (2009) menyimpulkan bahwa ada potensi untuk keunggulan kompetitif ketika TQM secara efektif diselaraskan dengan strategi organisasi dan dilembagakan dalam pengaturan organisasi "(Asif et al., 2009, p. 788). Para peneliti berpendapat bahwa metode terbaik tidak berada di dalam metodologi Six Sigma. Six Sigma tidak menyediakan sarana sistematis untuk menerjemahkan strategi organisasi ke dalam serangkaian matriks untuk mengukur, meningkatkan, dan mengendalikan. Untuk masalah ini, para peneliti berpendapat bahwa penyebaran BSC, akan memberikan kemampuan ini untuk menerjemahkan strategi operasional menjadi matriks tingkat tinggi yang dapat dipengaruhi oleh pengenalan inisiatif Six Sigma.

Kurangnya kemampuan solusi ini, merupakan tema penting dalam literatur pada Batasan Balanced Scorecard, dapat diatasi dengan memanfaatkan pemecahan masalah loop tertutup kekuatan metodologi Six Sigma. Juga, integrasi ini akan menghilangkan pemutusan strategis Six Sigma seperti yang dikatakan oleh Antony 
et al. (2006). Selain itu, BSC dan Six Sigma saling melengkapi dan berfungsi untuk menciptakan " combustion platform" untuk menyatukan BSC di dalam metodologi Six Sigma. Akhirnya, menyatukan BSC dengan Six Sigma memiliki potensi untuk membawa nilai tambahan bagi organisasi melalui kekuatan dan kelemahan pengungkit dan memungkinkan BSC dan metodologi Six Sigma untuk mewujudkan potensi penuh dalam organisasi.

Adapun kelebihan dari Six Sigma yaitu diantaranya pendekatan tersebut secara terus menerus sebagai pendekatan terbaik untuk proses perbaikan (Snee and Hoerl, 2003). Tidak ada pendekatan yang mengintegrasikan elemen manusia dan proses serta Six Sigma (Snee, 2004, hal. 9). Six Sigma secara unik didorong oleh pemahaman yang dekat tentang kebutuhan pelanggan, disiplin penggunaan fakta, data dan analisis statistik, dan perhatian untuk mengelola, meningkatkan dan menciptakan kembali proses bisnis (Pande et al., 2000, hal. 9). Kekuatan Six Sigma sebagian besar terletak dari fokus pelanggan ditambah dengan peningkatan yang terukur dalam Critical to Quality (Goh et al., 2006, hal. 236). Efektivitas Six Sigma berakar pada penerapan teknik statistic untuk pengumpulan informasi, analisis dan interpretasi (Goh dan Xie, 2004, hal. 236). Dalam program Six Sigma, tujuannya adalah untuk membangun apa yang diinginkan pelanggan sebagaimana tercermin oleh apa yang dikenal sebagai CTQ (Goh et al., 2006, hal. 236). Six Sigma memiliki peran strategis untuk dimainkan dalam organisasi (Goh dan Xie, 2004; Antony dan Banuelas, 2000 „, Pande et al., 2000). Six Sigma biasanya dilakukan berdasarkan proyek per proyek. Dengan pendekatan berbasis proyek, program Six Sigma dapat didefinisikan dan dikelola dengan lebih baik (Goh et al., 2006, hal. 236). Six Sigma dipandang memiliki dampak signifikan terhadap efisiensi operasional "(McAdam et al., 2005, p. 168).

Sedangkan kelemahan dari Six Sigma yaitu kurang dari 10 persen perusahaan melakukannya ke titik di mana hal tersebut akan secara signifikan mempengaruhi neraca dan harga saham dalam periode waktu yang berarti (Coronado dan Antony, 2002, p. 92). Makalah Douglas et al. (2009) memberikan bukti Six Sigma adalah pendekatan reduksionis. Douglas et al. (2009) berpendapat bahwa reduksionis pendekatan "bekerja dengan baik untuk yang sederhana, didefinisikan dengan baik. Masalah 'sulit' tetapi gagal berfungsi dengan baik pada masalah yang rumit dan tidak jelas serta ketika bagian dari masalah yang lebih kompleks dioptimalkan secara mandiri "(p. 144). "Sejumlah besar investasi diperlukan untuk melatih karyawan menjadi green belt, black belt, master black belt dan sebagainya" (Goh et al., 2006, p. 238). Prioritas proyek di banyak organisasi masih didasarkan pada penilaian subyektif murni. Sangat sedikit tools terbaik yang tersedia untuk memprioritaskan proyek dan hal ini harus menjadi dorongan utama untuk penelitian di masa depan "(Antony, 2004, hlm. 304). Pergeseran 1,5 Sigma terutama untuk layanan belum divalidasi (Goh et al., 2006). Tidak ada standar yang diterima secara seragam untuk sertifikasi personil Six Sigma (Goh et al.,2006). Kegagalan dapat terjadi karena solusi yang didorong oleh data yang mahal dan ini dapat 
mengakibatkan hanya sebagian kecil dari solusi yang telah diterapkan (Antony, 2004).

\section{HASIL DAN PEMBAHASAN}

\section{Integrasi Six Sigma dengan kerangka kerja BSC}

Selain nilai yang dapat diperoleh dengan memanfaatkan kekuatan dan kelemahan BSC dan Six Sigma, integrasi BSC dengan Six Sigma adalah terkait erat dengan temuan penelitian Cocks (2010) tentang organisasi dengan keunggulan kompetitif. Penelitian Cocks (2010) terhadap 1.000 organisasi Australia berpusat di sekitar hal yang menyeimbangkan perumusan strategi dengan pelaksanaan strategi yang efektif, memainkan peran penting dalam menjadi organisasi terbaik dan lebih penting daripada pemimpin karismatik, ide-ide terobosan dan kegiatan yang terkait dengan menciptakan struktur organisasi yang sempurna. Integrasi BSC dengan Six Sigma akan memungkinkan organisasi menerjemahkan strategi ke dalam matriks tingkat tinggi dan juga akan memberikan kemampuan untuk meningkatkan matriks tingkat tinggi melalui inisiatif Six Sigma.

Tinjauan literatur dengan jelas menguraikan manfaat Six Sigma dan BSC bagi organisasi. Secara paralel, kekuatan dan kelemahan literatur untuk Six Sigma dan BSC mengkristal bagaimana hal yang dapat menambah nilai lebih lanjut dibandingkan dengan implementasi mandiri baik BSC atau Six Sigma. Juga, Ahn (2005) membuat referensi ke rekomendasi Kaplan dan Norton (1996b, hal. 10) sehubungan dengan penggabungan misi dan strategi ke dalam BSC. Bersama-sama, penelitian Cocks (2010) dan tinjauan literatur tentang BSC dan Six Sigma memberikan alasan kuat untuk menggabungkan BSC dengan Six Sigma. BSC akan memberikan kemampuan untuk menerjemahkan strategi ke dalam matriks organisasi yang relevan dan Six Sigma akan menyediakan kendaraan untuk memengaruhi matriks. Selain itu, untuk kasus tertentu dari kegagalan BSC, Neely et al. (2004) mengajukan pertanyaan kunci: Apakah organisasi tidak menambah Balanced Scorecard dengan metodologi atau program peningkatan yang sesuai?. Fedotowsky (2010) menyelaraskan dengan pernyataan tersebut bahwa secara khusus memperhatikan sebagian dengan menekankan pentingnya menghubungkan BSC ke Six Sigma dengan menggunakan serangkaian matriks yang berjenjang. Namun, hal ini tidak memperhitungkan pentingnya menghubungkan matriks ke metodologi peningkatan yang sesuai (Neely et al., 2004, hal. 768). Istilah "metodologi peningkatan yang tepat" menurut (Neely et al., 2004, p. 768) adalah poin kunci karena tidak semua matriks organisasi yang ada cocok dengan metodologi Six Sigma. Semua poin ini membentuk dasar untuk kerangka kerja yang ditunjukkan pada Gambar 1 . 


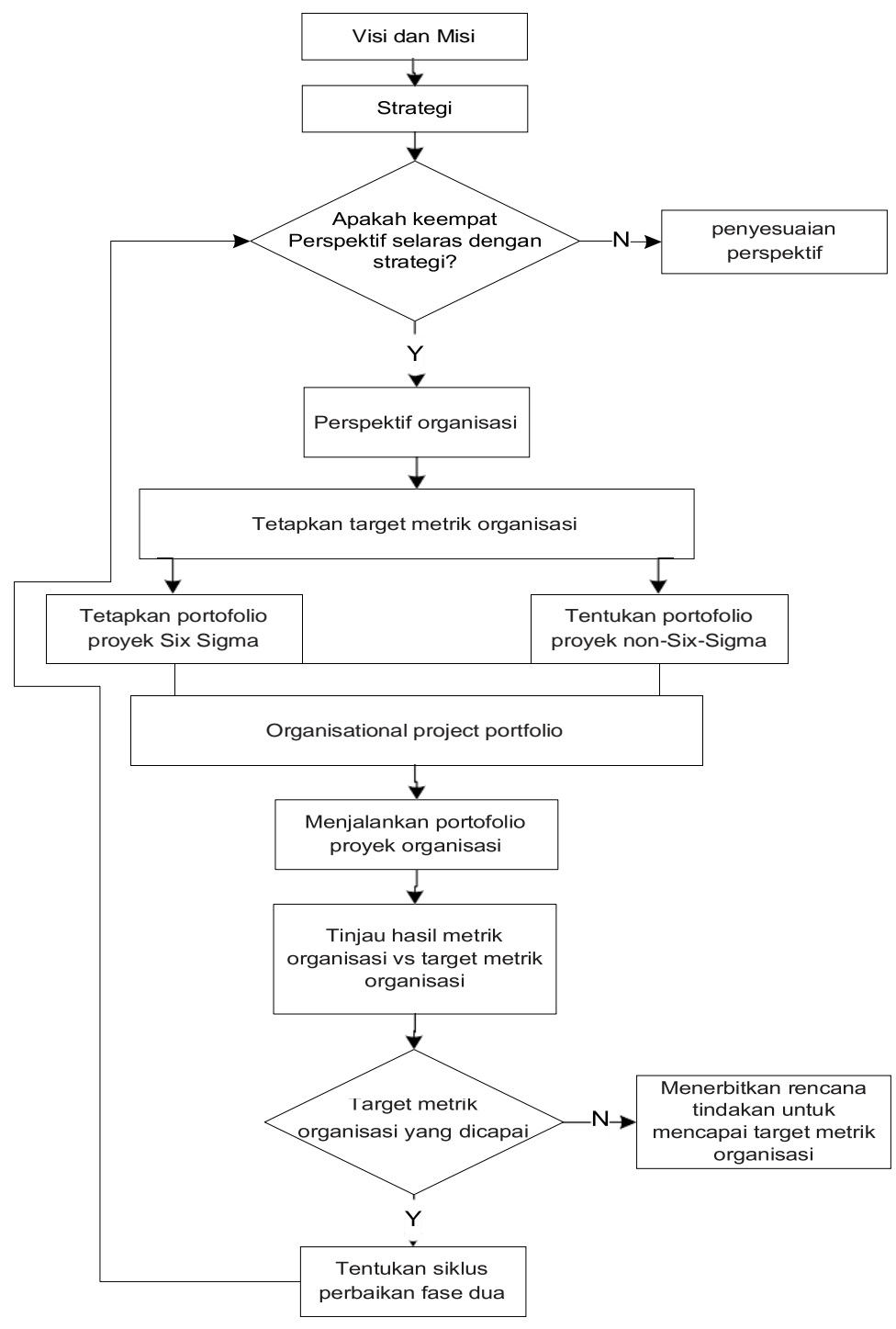

Gambar 1. Kerangka kerja untuk Integrasi Balanced scorecard-Six Sigma

Kerangka kerja yang digambarkan dalam Gambar 1 didasarkan pada siklus empat tahap Plan-Do-Check-Action (PDCA), "diagram alur untuk pembelajaran dan peningkatan proses" (Pyzdek, 2001, hal. 8), yang dipopulerkan oleh Deming . Mirip dengan PDCA, prinsip dasar dari kerangka kerja pada Gambar 1 adalah iterasi (Pyzdek, 2001). Sebagai contoh, begitu target matriks organisasi telah dipenuhi, siklus perbaikan kedua dapat dimulai dan laju perbaikan dapat dilacak untuk setiap siklus sebagaimana diuraikan oleh makalah paruh waktu Schneiderman (Schneiderman, 1986, 1988). Atau, jika target matriks organisasi belum tercapai, rencana aksi dibuat untuk menutup kesenjangan antara target matriks dan hasil 
aktual. Juga, kerangka kerja pada Gambar 1 memungkinkan organisasi untuk menyesuaikan perspektif dan kemudian berdasarkan perspektif ini, untuk menentukan portofolio Six Sigma dan portofolio Non-Six-Sigma yang akan mempengaruhi matriks tingkat tinggi di BSC. Sebagai contoh, total portofolio organisasi dapat terdiri dari Define, Measure, Analysis, Improve dan Control (DMAIC) dan Define for inisiatif Six Sigma digabungkan dengan inisiatif lain seperti inisiatif Manajemen Proyek. Dengan demikian, hal ini memiliki efek keseluruhan yang menyelaraskan berbagai elemen strategi ke metodologi yang benar untuk pelaksanaan yang efektif dan efisien. Dengan cara ini, sumber daya disejajarkan dengan benar dan tidak efisien alokasi sumber daya yang terjadi. Untuk setiap matriks organisasi, organisasi akan perlu melakukan pemahaman mendalam ke berbagai tingkat sub proses dalam organisasi dan kemudian memutuskan critical faktor yang akan dieksekusi sebagai bagian dari portofolio proyek organisasi (PMI, 2004, hal. 16). Akhirnya, dalam gambaran ini, para peneliti berpendapat bahwa kerangka kerja integrasi pada Gambar 1 adalah fleksibel, kuat dan kerangka kerja efisien yang berlaku untuk semua organisasi yang terlibat dalam peningkatan kinerja dan memiliki potensi untuk membawa manfaat strategis yang cukup besar bagi organisasi mana pun.

\section{KESIMPULAN}

Kontribusi utama dari makalah ini adalah bahwa hal ini memberikan wawasan baru dalam memahami nilai mengintegrasikan BSC dengan Six Sigma dan kedua, makalah ini mengusulkan kerangka kerja yang menyatukan BSC dan Six Sigma. Makalah ini menunjukkan bahwa BSC adalah alat yang efektif untuk menerjemahkan strategi menjadi ukuran kinerja tingkat tinggi. Menambahkan Six Sigma ke kerangka kerja ini akan memberi organisasi kemampuan untuk mempengaruhi dan mengendalikan matriks secara sistematis dan terstruktur. Kekuatan dan kelemahan literatur untuk Six Sigma dan BSC dapat diintegrasikan dimana hal ini dapat menambah nilai lebih lanjut dibandingkan dengan berjalan secara terpisah dari implementasi baik BSC atau Six Sigma. Dihadapkan dengan lingkungan bisnis yang semakin kompleks dan bergejolak, organisasi memerlukan hubungan yang kuat antara strategi dan eksekusi strategi yang efektif. Para peneliti berpendapat bahwa integrasi BSC dengan Six Sigma adalah pusat dari kebutuhan yang akan mendorong efisiensi dan inovasi ke dalam bisnis, yang pada gilirannya bertindak sebagai platform untuk keunggulan kompetitif yang berkelanjutan. Six Sigma bukanlah obat mujarab untuk semua penyakit organisasi. Namun, integrasi Six Sigma yang efektif dengan BSC akan memberikan ikatan yang kuat antara strategi organisasi dan eksekusi strategi dan memungkinkan organisasi untuk mewujudkan potensi penuh dari BSC dan Six Sigma. Singkatnya, dirancang dan digunakan dengan benar menggunakan perubahan manajemen proses yang kuat, BSC dalam kombinasi dengan Six Sigma, akan mengartikulasikan dan melaksanakan strategi bisnis, dan akan bertindak sebagai platform untuk keunggulan dan peningkatan bisnis. 


\section{DAFTAR PUSTAKA}

Ahmed, N. G., Abohashima, H. S., \& Aly, M. F. (2018). Defect Reduction Using Six Sigma Methodology in Home Appliances Company: A Case Study. Proceedings of the International Conference on Industrial Engineering and Operations Management, 1349-1358

Ahn, H. (2005), "How to individualise your balanced scorecard", Measuring Business Excellence, Vol. 9 No. 1, pp. 5-12.

Amaratunga, D., Baldry, D. and Sarshar, M. (2001), "Process improvement through performance measurement: the balanced scorecard methodology", Work Study, Vol. 50 No. 5, pp. 179-88.

Anagnostopoulos, K.P. and Elmasides, G. (2010), "Strategic plan in a Greek manufacturing company: a balanced scorecard and strategy map implementation", Journal of Business \& Management, Vol. 5 No. 2, pp. 1225.

Antony, J. and Banuelas,R. (2000), "Key ingredients for the effective implementation of Six

Sigma program", Measuring Business Excellence, Vol. 6 No. 4, pp. 20-7.

Antony, J. (2004), "Some pros and cons of Six Sigma: an academic perspective", TQM Magazine, Vol. 6 No. 4, pp. 303-6.

Antony, J., Kumar, M. and Madu, C.N. (2005), "Six Sigma in small- and mediumsized UK manufacturing enterprises: some empirical observations", International Journal of Quality and Reliability Management, Vol. 22 No. 8, pp. 860-74.

Antony, J., Banuelas, R. and Kumar, A. (2006), World Class Applications of Six Sigma, Butterworth-Heinemann Ltd, Oxford.

Aravamudhan, S. and Kamalanabhan, T.J. (2007), "An AHP study on the critical factors for balanced scorecard implementation in Indian organisations", International Journal of Business Innovation and Research, Vol. 1 No. 3, pp. 387-403.

Asif, M., Bruijn, E.J., Douglas, A. and Fisscher, O.A.M. (2009), "Why quality management programs fail: a strategic and operations management 
perspective", International Journal of Quality and Reliability Management, Vol. 26 No. 8, pp. 778-94.

Bourne, M., Neely, A., Mills, J. and Platts, K. (2002), “The success and failure of performance measurement initiatives", International Journal of Operations \& Production Management, Vol. 22 No. 11, pp. 1288-310.

Cocks, G. (2010), "Emerging concepts for implementing strategy", Total Quality Management Journal, Vol. 22 No. 3, pp. 260-6.

Colm Heavey and Eamonn Murphy (2010), Integrating the Balanced Scorecard with Six Sigma, The TQM Journal Vol. 24 No. 2, 2012 pp. 108-122

Coronado, R.B. and Antony, J. (2002), "Critical success factors for the successful implementation of Six Sigma projects in organisations", Total Quality Management Magazine, Vol. 14 No. 2, pp. 92-9.Dabhilkar, M. and Bengtsson, L. (2004), "Balanced scorecards for strategic and sustainable continuous improvement capability”, Journal of Manufacturing Technology Management, Vol. 15 No. 4, pp. 350-9.

Deamonita, A. I., \& Damayanti, R. W. (2018). Pengendalian Kualitas Tas Tali Batik di PT XYZ dengan menggunakan Metode Six Sigma. Seminar dan Konferensi Nasional IDEC, 161-169

Dr Robert S Kaplan”, Measuring Business Excellence, Vol. 7 No. 1, pp. 30-5.

Douglas, A., Middleton, S., Antony, J. and Coleman, S. (2009), "Enhancing the Six Sigma problem- solving methodology using the systems thinking methodologies", International Journal of Six Sigma and Competitive Advantage, Vol. 5 No. 2, pp. 144-55.

Epstein, M. and Manzoni, J.F. (1998), "Implementing corporate strategy: from tableaux de bord to balanced scorecards", European Management Journal, Vol. 16 No. 2, pp. 190-203.

Fedotowsky, A. (2010), “Added traction”, Quality Progress, Vol. 44 No. 6, pp. 45 51. George, M.L. (2003), Lean Six Sigma for Services, McGraw-Hill, New York, NY.

Gillett, J., Fink, R. and Bevington, N. (2010), "How catterpillar uses 6 sigma to execute strategy", Strategic Finance, Vol. 91 No. 10, pp. 25-8.

Goh, T.N. and Xie, M. (2004), "Improving on the Six Sigma paradigm", TQM Magazine, Vol. 16 No. 4, pp. 235-40. 
Goh, T.N., Tang, C.L., Lam, S.W. and Gao, Y.F. (2006), "Six Sigma: a SWOT Analysis", International Journal of Six Sigma and Competitive Advantage, Vol. 2 No. 3, pp. 233-42.

Gumbus, A. and Lyons, B. (2002), "The balanced scorecard at Philips electronics", Strategic Finance, Vol. 4 No. 11, pp. 46-8.

Hammer, M. (2002), "Process management and the future of Six Sigma", MIT Sloan Management Review, Vol. 43 No. 2, pp. 26-32.

Hendricks, C.A. and Kelbaugh, R.L. (1998), "Implementing Six Sigma at GE”, The Journal for Quality \& Participation, Vol. 21 No. 4, pp. 48-53.

Hepworth, P. (1998), "Weighing it up - a literature review for the balanced scorecard", Journal of Management Development, Vol. 17 No. 8, pp. 55963.

Hoerl, R. (2004), "One perspective on the future of Six Sigma”, International Journal of Six Sigma and Competitive Advantage, Vol. 1 No. 1, pp. 112-9.

Huesing, T. (2008), "Six Sigma through the years", available at: http://6sigmaexperts.com/presentations/Six_Sigma_Through_the_Years.pdf (accessed 14 January 2011).

Kaplan, R.S. (1993), "Implementing the balanced scorecard at FMC corporation: an interview with Larry Brady", Harvard Business Review, Vol. 71 No. 5, pp. 143-7.

Kaplan, R.S. and Norton, D.P. (1992), "The balanced scorecard-measures that drive performance", Harvard Business Review, Vol. 70 No. 1, pp. 71-9.

Kaplan, R.S. and Norton, D.P. (1996a), "Linking the balanced scorecard to strategy", California Management Review, Vol. 39 No. 1, pp. 53-79.

Kaplan, R.S. and Norton, D.P. (1996b), The Balanced Scorecard - Translating Strategy into Action, Harvard Business School Press, Boston, MA.

Kaplan, R.S. and Norton, D.P. (2001), "Transforming the balanced scorecard from performance measurement to strategic management: part 1", Accounting Horizons, Vol. 15 No. 1, pp. 87-104.

Kaplan, R.S. and Norton, D.P. (2007), "Using the balanced scorecard as a strategic management system", Harvard Business Review, Vol. 85 Nos 7/8, pp. 15061. 
Marr, B. and Schiuma, G. (2003), "Business performance - past, present and future", Management Decision, Vol. 41 No. 8, pp. 680-7.

McAdam, R. and Lafferty, B. (2004), “A multilevel case study critique of Six Sigma: statistical control or strategic change?", International Journal of Operations \& Production Management, Vol. 24 No. 5, pp. 530-49.

McAdam, R., Hazlett, S.A. and Henderson, J. (2005), "A critical review of Six Sigma: exploring the dichotomies", International Journal of Organisational Analysis, Vol. 13 No. 2, pp. 151-74.

McCunn, P. (1998), "The balanced scorecard: the eleventh commandment", Management Accounting, Vol. 76 No. 11, pp. 34-6.

Metri, B.A. (2007), "Measuring corporate performance with the Six Sigma business scorecard", Journal of Business Perspective, Vol. 11 No. 3, pp. 59-65.

Montgomery, D. (2001), "Editorial, beyond Six Sigma”, Quality and Reliability. Engineering International, Vol. 17 No. 4, pp. iii-iv.

Nakhai, B. and Neves, J.S. (2009), "The challenges of Six Sigma in improving service quality", International Journal of Quality and Reliability Management, Vol. 26 No. 7, pp. 663-84.

Narayanamma, P. L. (2017). A Study On Impact Of Balanced Scorecard Implementation On Job Satisfaction Of Employees In Selected Public And Private Sector. Shanlax International Journal of Arts, Science and Humanities, 4(3), 44-52

Neely, A., Adams, C. and Kinnerley, M. (2001), The Performance Prism: The Scorecard for Measuring and Managing Stakeholder Relationships, Pearson Education Ltd, London.

Neely, A., Kennerley, M. and Martinez, V. (2004), "Does the balanced scorecard work? An empirical investigation", in Neely, A., Kennerley, M. and Walters, A. (Eds), Performance Measurement and Management - Public and Private, Centre for Business Performance, Cranfield, pp. 763-70.

Neely, A.D., Gregory, M.J. and Platts, K.W. (2005), "Performance measurement system design: a literature review and research agenda", International Journal of Operations \& Production Management, Vol. 25 No. 12, pp. 1228-63. 
Noorein, I. and Kaplan, R.S. (2002), "Applying the balanced scorecard in health care provider organisations”, Journal of Healthcare Management, Vol. 47 No. 3, pp. 179-95.

Nørreklit, H. (2000), "The balance on the balanced scorecard: a critical analysis of its assumptions", Management Accounting Research, Vol. 11 No. 1, pp. $65-88$.

Olve, N., Roy, J. and Wetter, M. (1999), Performance Drivers: A Practical Guide to Using the Balanced Scorecard, John Wiley \& Sons, Chichester.

Othman, R. (2008), "Enhancing the effectiveness of the balanced scorecard with scenario planning", International Journal of Productivity and Performance Management, Vol. 57 No. 3, pp. 259-66.

Pande, P.S., Neuman, R.P. and Cavanagh, R.R (2000), The Six Sigma Way - How GE, Motorola and other Top Companies are Honing Their Performance, McGraw-Hill, New York, NY.

Pepper, M.P.J. and Spedding, T.A. (2010), "The evolution of Six Sigma", International Journal of Quality and Reliability Management, Vol. 27 No. 2, pp. 138-55.

Phengky Pangestu \& Fakhrina Fahma (2019)." Implementasi Six Sigma dalam Peningkatan Kualitas Proses Produksi LED TV di PT Sharp Electronics Indonesia”. Performa (2018) Vol. 17, No.19: 152-164

Pineno, C. and Christini, C. (2003), "The balanced scorecard: a vision report card", Management Accounting Quarterly, Vol. 4 No. 4, pp. 28-40.

PMI (2004), A Guide to the Project Management Body of Knowledge, 3rd ed., PMI Publishing, Pennsylvania, PA.

Pyzdek, T. (2001), The Six Sigma Handbook: A Complete Guide for Greenbelts, Blackbelts, Managers at all Levels, McGraw-Hill, New York, NY.

Pyzdek, T. (2004), "Strategy deployment using balanced scorecards", International Journal of Six Sigma and Competitive Advantage, Vol. 1 No. 1, pp. 21-8.

Rowe, M. and White, B. (2009), "Cover your bases: double up your approach to guarantee successful improvement”, Quality Progress, Vol. 43 No. 12, pp. 54-9.

Schneiderman, A.M. (1986), "Optimum quality costs and zero defects: are they contradictory concepts?”, Quality Progress, Vol. 19 No. 11, pp. 1-4. 
Schneiderman, A.M. (1988), "Setting quality goals", Quality Progress, Vol. 21 No. 4, pp. 51-7. Schneiderman, A.M. (1999), "Why balanced scorecards fail", Journal of Strategic Performance Measurement, Vol. 3 No. 1, pp. 6-11.

Schultz, B. (2010), "Merging Six Sigma and the balanced scorecard", available at: www.isixsigma.com/index.php?option $1 / 4$ com_k2\&view1/4item\&id1/41406:me rging-six-sigma- and-the-balanced-scorecard\&Itemid1/4165 (accessed 14 January 2011).

Self, J. (2004), "Metrics and management: applying the results of the balanced scorecard", Performance Management and Metrics, Vol. 5 No. 3, pp. 101-5.

Silk, S. (1998), “Automating the balanced scorecard", Management Accounting, Vol. 79 No. 11 , pp. $38-42$.

Smith, M. (2005), “The balanced scorecard”, Financial Management, Vol. 13 No. 1, pp. 27-8.

Snee, R.D. and Hoerl, R.W. (2003), Leading Six Sigma: A Step by Step Guide Based on Experience at GE and Other Six-Sigma Companies, Financial Times Prentice Hall, Upper Saddle River, NJ.

Snee, R.D. (2004), "Six Sigma: the evolution of 100 years of business improvement", International Journal of Six Sigma and Competitive Advantage, Vol. 1 No. 1, pp. 4-20.

Snee, R.D. (2010), "Lean Six Sigma- getting better all the time”, International Journal of Lean Six Sigma, Vol. 1 No. 1, pp. 9-29.

Solano, J., DeOvalles, M.P., Rojas, T., Padua, A.G. and Morales, M.L. (2003), "Integration of Systemic Quality and the Balanced Scorecard", Information Systems Management, Vol. 20 No. 1, pp. 66-81.

Urrutia, I. and Eriksen, S.D. (2005), "Application of the balanced scorecard in Spanish private health-care management", Measuring Business Excellence, Vol. 9 No. 4, pp. 16-26.

Valles, A., Sanchez, J., Noriega, S., \& Nunez, B. G. (2009). Implementation of Six Sigma in a Manufacturing Process: A Case Study. International Journal of Industrial Engineering, 171-181

Thomsett, M. C. (2005). Getting Started in Six Sigma. New Jersey: John Wiley \& Sons, Inc 